\title{
EMBRYONIC STEM CELLS: WHERE DO WE STAND AT THE MOMENT?
}

\author{
Sanja Raščanin ${ }^{1}$, Nemanja Rančić2 , Saša Dragović3 , Mirjana Jovanovići,
}

\begin{abstract}
Stem cells are functionally defined as cells that have the ability to self-replicate and generate differentiated cells. They can generate multiple differentiated cell types (multipotent or pluripotent) or produce one type of differentiated cells (unipotent) depending on the replication capacity and potency of stem cells. Today stem cells might have potential application in regenerative medicine, transplantation, treatment of autoimmune, chronic and progressive diseases, as well as disease modelling. Now we are faced with a dilemma between the two types of stem cells, which are more suitable for research and therapeutic use, which will be Embryonic Stem Cells (ESC) or Induced Pluripotent Stem Cells (iPSC)? ESCs represent the gold standard of pluripotency in vitro, which compares all other types of stem cells, but iPSC are more convenient in autologous transplants because of the avoidance of tissue rejection and without ethical concerns. The aim of this paper is presenting the most important characteristics of the ESCs which have therapeutic significance.
\end{abstract}

Acta Medica Medianae 2019;58(3):138-146.

Key words: embryonic stem cells, legislation, therapy

\author{
${ }^{1}$ University of Kragujevac, Faculty of Medical Sciences, \\ Kragujevac, Serbia \\ ${ }^{2}$ Center for Clinical Pharmacology, Military Medical Academy, \\ Belgrade, Serbia \\ ${ }^{3}$ Clinic for general surgery, Military Medical Academy, Belgrade, \\ Serbia \\ ${ }^{4}$ Psychiatric Clinic, Clinical Center Kragujevac, Kragujevac, \\ Serbia
}

Contact: Sanja Raščanin

Svetozara Markovića 69, 34000 Kragujevac, Serbia

E-mail: rsanja.eko@gmail.com acteristics, the other being the progenitor cell which is the intermedia cell between the stem cell and the target tissue cell whose division is limited). Clonogenicity is the ability to create clones, or cells with identical genetic material, while the potential of stem cells is the ability to differentiate into different types of specialized cells $(1,2)$.

\section{Classification of stem cells}

Fertilization of an egg results in a diploid zygote that is dividing rapidly into 16 -cells that form so called morula. The cells continue dividing and generating blastocyst by multiple mitotic cell divisions during early embryogenesis occurs. The blastocyst consists of an outer layer of cells called trophoblast (trophectoderm) and an inner layer of cells called the embryoblast. The trophectoderm also known as the outer cell mass forms the extraembryonic tissue that might give rise to placenta, chorion and the umbilical cord. The embryoblast also known as the inner cell mass (ICM) develops into the embryo (3, 4). Totipotent embryonic stem cells have the potential to develop into any type of cells or to form the entire organism. The definition of totipotency is based on the capacity of a single cell to contribute to all lineages (5). The only cells which own that ability are the cells generating during early embryogenesis so called blastomeres that form morula $(1,2,5)$. According to the capacity for differentiation, stem cells can be classified into several types: pluripotent, multipotent and unipotent stem cells $(1,2)$. Pluripotent stem cells have the ability to differentiate into almost all cell types, giving different types of metric (one daughter cell retains the stem cell char- 
cells that develop from three germ layers (mesoderm, endoderm and ectoderm) from which all the cells in the body are formed. The sources of human pluripotent stem cells were isolated from are early human embryos, i.e. from the internal cell mass of the blastocyst (embryo 4 - 5 days old, which has 50 - 150 cells) - so called embryonic stem cells, and from the fetal tissue that was predetermined to be part of the gonads, embryonic germinal cells. The ectoderm develops: skin, hair, nails, skin glands, eyes, mouth, nose, pigment cells, nerve cells, spinal cord, brain and others. The mesoderm develops: muscles, connective tissue, skeleton, heart, blood vessels, blood cells, urogenital system, gonads, fat cells and others. The endoderm develops: throat, extremities, salivary glands, pancreas, liver, lungs, thymus, thyroid gland, paralytic gland and others. They can give rise to all tissue types, but they cannot give rise to an entire organism $(1,2)$. Multipotent stem cells have the ability to differentiate into cells which come from one germ layer or single tis-sue cells. An example of multipotent stem cells are hematopoietic stem cells or mesenchymal stem cells from the bone marrow that can differentiate into bone, cartilage and fat tissue cells. They are pro-genitor cells that give rise to a limited range of cells within a tissue type $(1,2)$. Unipotent stem cells have the potential to differentiate into only one type of cells. They came from multipotent cells and have limited potential for differentiation, but retain the ability to self-renewal. An example of unipotent stem cells are limbal cells (enabling the regeneration of the eye tissue and the ocular nerve, they are found along the length of the iris) and epithelial cells. They are precursor cells (1, 2 ). In relation to the function of the stem cells in organism, they might be clas-sified into normal and cancerous stem cells. Cancer-ous stem cells (CSCs) have been identified in many tumors, some of the cluster of differentiation (CD) that identifies cell surface antigens were also found in CSCs (2).

Bonnet 1997 (6) identified CD34+/CD38- in acute myeloid leukemia. Al-Hajj 2003 (7) identified CD44+/CD24- in breast cancer, in the same year Singh (8) identified CD133+ in brain tumor. Matsui 2004 (9) identified CD138+ in multiple myeloma. In 2007, O'Brien (10) and Ma (11) identified same surface antigen CD133+ in colon cancer and liver cancer, in the same year Li (12) identified CD44+/ CD24+ in pancreatic cancer. In 2008 Eramo (13) identified CD133+ in lung cancer. Many other surface antigens such as CD133+/CD44+ in prostate cancer by Maitland (14), CD44+/CD117+ in ovary cancer by Zhang (15), and CD4+/CD25+/FoxP3+ in melanoma by Schatton (16) were identified in the same year. In 2009, Takaishi (17) identified CD44+ in gastric cancer. Compared to the source of isolation stem cells might be classified into embryonic, fetal, adult and induced pluripotent stem cells (1, 2, 18). Embryonic stem cells (ESCs) are isolated from the inner cell mass of the embryo before its implantation (19). Human Embrionic Stem Cells (hESCs) have the ability to generate cells from all three embryonic germ layers and also represent great candidate cells source for therapeutic uses (1,
$2,18,20)$. Fetal stem cells (FSCs) are isolated from the fetus after abortion or umbilical cord blood (e.g. hematopoietic stem cells), $(1,2,18)$. Adult stem cells (ASCs) are undifferentiated cells, found in different tissues and organs, between differentiated cells. These stem cells could be of different origin e.g., endodermal origin are gastrointestinal tract stem cells, pulmonary epithelial stem cells, hepatic oval cells, pancreatic stem cells, ovarian and testicular stem cells, mammary and prostatic gland stem cells; mesodermal origin are mesenchymal stroma stem cells, mesenchymal precursor stem cells, mesenchymal stem cells, hematopoietic stem cells, cardiac stem cells, multipotent adult progenitor cells, bone marrow stem cells, fetal somatic stem cells, unrestricted somatic stem cells, satellite cells of muscle; ectodermal origin are skin stem cells, neural stem cells, ocular stem cells. They have the capacity for self-renewal and multiline differentiation; they differentiate into the tissue cells in which they are found. The primary role of adult stem cells is to repair damaged tissue $(1,2,18)$. Induced pluripotent stem cells (iPSCs) are generated by reprogramming terminally differentiated cell genome to the stage of pluripotent stem cell in vitro induction and by the forced expression of certain gene and factors that are important for the maintenance of pluripotency (Sox2, Oct3.4, c- Myc, KLF4). These stem cells have common features with Embryonic Stem Cells in terms of morphology, surface antigen expression, proliferation, gene expression, and telomerase activity. They can be differentiated into the cells of all three germ layers $(1,2,18)$.

\section{Morphological characteristics of embryonic stem cells}

In vitro embryonic stem cells (ESCs) grow in flat colonies with clear boundaries of cells in the monolayer of culture. They produce small, round colonies, and at the cellular level show a high ratio of nucleotide-cytoplasm with one or more prominent nucleolus and a characteristic spacing between the cells. Embryonic stem cells are identified by the expression of surface cell antigens as stage specific embryonic antigen (SSEA 3 and 4) and tumor rejection antigen (TRA-1-60 and TRA-1-81) used as markers for undifferentiated ESCs (21). These globular glycolipids are recognized by monoclonal antibodies $^{1}$. During the differentiation of ESC, the poor regulation of SSEA-3 and SSEA-4 is observed. ESCS are characterized by high activity of telomerase and alkaline phosphatase, as well as the activity of genes necessary for the maintenance of cells pluripotency. All cell lines of ESCs express high levels of telomerase, an enzyme that helps maintain telomeres that protect the ends of the chromosomes. Telomerase activity and long telomeres are features of proliferative cells in embryonic tissues and germ

${ }^{1}$ Monoclonal antibodies are homogeneous populations of identical antibody molecules that are derived from an antibodyproducing cell with specificity for a particular epitope. Epitopes are antigenic determinants that recognize the antibody and bind to antibody. 
cells. Somatic cells do not show telomerase activity and their telomers are significantly shorter. In contrast to ESCS, differentiated somatic cells are not shared in culture - the phenomenon of replication aging. Embryonic stem cells are also defined by the presence of various transcription factors and surface proteins. Specific transcription factors (pluripotent stem cells markers) such as octamer-binding transcription factor 3/4 (OCT3/4), Homeobox protein NANOG (NANOG), SRY (sex determining region $Y$ )box2 (SOX2), Myelocytomatosis cancers (c-Myc), Kruppel-like factors (KIf4), Growth and differentiation factor 3 (GDF3), Reduced expression 1 (REX1), Fibroblast growth factor 4 (FGF4), Embryonic cellspecific gene 1 (ESG1), Developmental pluripotencyassociated 2 (DPPA2), DPPA4 and Telomerase reverse transcriptase (TERT) play a role in retaining pluripotence and inducing genes that lead to differentiation. Oct4 is a classic proto-oncogene whose abnormal expression extends to the dysplastic growth and formation of various types of tumors, and affects the malignancy of ES cells in vitro. Sox 2 is also proto-oncogene. Klf4 was also identified as a potential oncogene and as a tumor suppressor. cMyc is proto-oncogene, increased expression is observed in more than $70 \%$ of various human tumors, making it one of the most commonly detected tumor markers $(1,2,18,21,22)$.

\section{stem cells}

The functional characteristics of the ESCS include the following criteria: embryonic stem cells can be isolated from the inner cell mass of the blastocyst; they are capable of prolonged proliferation in culture without differentiation; ESCs are pluripotent, and can differentiate spontaneously into multiple cell types representative of all three embryonic germ layers, both in teratomas after grafting or in vitro under appropriate conditions; embryonic stem cells do not show $\mathrm{X}$-chromosome inactivation; they can maintain a normal diploid cariotype in vitro; embryonic stem cells can be cloned, i.e. they have the ability to form a homogeneous cell line with all the characteristics of the parent ESCs; ESCs can remain in the S-phase of the cell cycle most of their lifetime; they can express a high level of Oct4 a transcription factor known to be involved in their self-renewal process; embryonic stem cells may be induced to differentiate after continuous cultivation in an undifferentiated state $(1,2,23,24)$.

\section{Derivation of embryonic stem cells}

Three different methods can be used for derivation of ESCS, depending on the morphology of the blastocyst and the appearance of internal cell mass (ICM). There is a strong relationship between the shape and size of the ICM of blastocyst and its viability. Immunosurgical method is used for blastocysts with large and distinct ICMs. The partial-embryo culture method is used for expanded blastocysts with distinct but smaller ICMs. The wholeembryo culture method is used in cases in which the blastocyst exhibited an indistinguishable ICM and trophoectoderm. Isolation of the ESCs line is a relatively simple procedure with a success of $30-50 \%$ $(1,25,26)$. Solter and Knowles (1975) (27) developed a procedure known as immunosurgery for selective isolation within the cellular mass of blastocysts to investigate early embryonic development. This method of selective isolation of the intracellular mass of blastocysts was the basis of the first ESCs line derived from the mouse blastocyst. The process involves several stages. Initially, the glycoprotein external layer of the pelucide zone is dissolved by Tyrode's solution or by enzyme pronasa. The exposed embryo is then incubated for about 30 minutes in antihuman-whole-serum antibodies. The pennetration of antibodies into the blastocyst is prevented by cellular connections within the outer layer of trophoblasts, leaving the intracellular mass of blastocysts intact. After washing the residuals of the antibody, the blastocyst is transferred to the medium and incubated once until the cell line of the trophoectoderm is reached. Since the pelucide zone allows the antibody to penetrate, the complement of proteins formed after the lysis can be alternatively removed. After selective removal of trophoectoderm, the intact intracellular mass is further cultured on mitotic-inactivated MEFs (Mouse Embryo Fibroblast) $(1,25,27)$. Partial-embryo culture method usually used forblastocysts with smaller ICM and higher risk of losing their ICMs when processed via immunosurgery. ESCs lines can be isolated directly from cultured blastocysts by mechanical dissection and partially removing the trophoblast layer using a 27G needle or by drawing Pasteur pipette onto mitotically inactivated embryonic fibroblasts. When the trophoblasts are only partially removed or unglazed, embryos attach to the nutrient layer and align, allowing continuous growth within the cell mass, with the remaining surrounding single-layer trophoblasts. When the intra-cell mass reaches the required size, it is selectively removed and propagated. This method has a significantly lower success rate compared to immunosurgery due to tendencies of intra-cellular mass to differentiate $(1,25)$. Wholeembryo culture method is used for blastocysts with no visible ICM, carried out by seeding whole blastocysts without the pelucid zone directly on the STOfeeder layer. The excessive growth of trophoectoderms tends to prevent the spread of ICMs during the initial steps of the ESCs derivation. There-fore, a partial-embryo culture method for the pro-duction of ESCs from blastocysts with a smaller ICM was developed (25).

\section{Cultivation of embrionic stem cells}

The cultivation of ESCs is done in a few steps. The pluripotent stem cells are isolated from the inner cell mass of the blastocyst, by the before mentioned methods (e.g., immunosurgery) and then cultured on mitotic-inactivated embryonic fibroblasts of mice (MEFs); MEFs are usually inactivated by mitomycin-C or $\mathrm{Y}$-radiation to prevent its replication. Although ESCs require precise care, they can be cultivated in large numbers and frozen and defrosted with a good survival rate. The ESCs cultures have the ability to grow in serum-free conditions; they 
can use human "feeder" layers as substitutes for MEFs and can be maintained in an undifferentiated state in food-free conditions. During cultivation of ESCs in MEFs with Fetal Bovine Serum (FBS) enriched medium, there is a risk of cells exposure to retroviruses or other pathogens. One of the solutions to this problem is the isolation and cultivation of hESCs in an environment that is completely without animal origin. In the culture medium, FBS was replaced by the addition of $20 \%$ human serum, and MEFs was replaced by the human "feeder" layer. However, many hESCs lines, such as NTERA2 lines, do not depend on the "feeder" layers $(1,22,28)$. Pluripotent stem cells that were isolated from inner cell mass of human blastocysts belong to one of the five hESCs lines - H1, H7, H9, H13 and $\mathrm{H} 14$. After 9 to 15 days, the inner cell mass is dividing, mechanical grouping and replating some of the cells under conditions of the same culture and that result in creation of different cells lines. The hESCs lines, which grew in the culture of high-density suspension, will form embryonic bodies. Embryonic bodies are groups of cells that form when the hESCs are cultivated on plates or in the medium and do not occur under natural conditions. Embryonic bodies contain undifferentiated and partially differentiated cells (19). However, the hESCs remain undifferentiated when cultivated in high density. The hESCs can be differentiated into the cells of all three germ layers in vitro and they can form teratomas in vivo (tumors built from undifferentiated and differentiated cells) after injection into immunodeficient mice. The hESCs lines carry genetic variations related to tumor genes that limit their differentiation capacity) $(1,22,28)$. In vivo, after injection into immunocompromised mice, hESCs differentiate into bone, cartilage, squamous epithelium, nerve cells, glandular epithelium, striated muscles and also teratomas (1, $19,22,28)$.

\section{The importance of "Feeder" cells, growth factors and serum-free media for cultivation of ESCS}

In the 1970s, pluripotent teratocarcinoma (stem cells) cell lines were obtained after the introduction of a "feeder" cells layer. "Feeder" cells (boost cells) were useful in the study of teratocarcinoma (stem cell) and embryonic carcinoma (EC) cells. "Feeder" cells are usually inactivated by mitomycin$\mathrm{C}$ or $\mathrm{Y}$-radiation. Although the "feeder" cells live, they do not replicate. The "feeder" layer has a dual role: first, mouse embryonic fibroblasts (MEFs) support hESCs growth; second, MEFs prevent spontaneous differentiation of hESCs during cultivation. MEFs maintain pluripotency of the hESCs, a secreting factor identified as leukemia inhibitory factor (LIF), also known as differentiation inhibiting activity (DIA). ESCs colonies are cultured on "feeder" cells in the presence of serum and growth factor cocktails, such as leukemia inhibitory factor, stem cells factor (SCF) and basic fibroblast growth factor (bFGF). Without the "feeder" layer, cultured embryonic stem cells will not remain pluripotent, suggesting that fibroblasts promote either self-renewal or suppress differentiation or both. LIF is sufficient to guarantee self-renewal ESCs in a serum enrichment environment. However, when the ESCs are cultured in a serum-free medium containing LIF, they tend to spontaneously undergo neural differentiation. This indicates the existence of one or more growth factors contained in the Fetal Calf Serum (FCS), which together with LIF participates in the maintenance of pluripotence of the ESCs. Ying and associates (29) identified Bone morphogenetic protein 4 (BMP4) as a growth factor that works in combination with LIF to maintain self-renewal, as well as to prevent/block neural differentiation of ESCs in a culture without serum. The activity of BMPs was first identified in the 1960s (30), the proteins responsible for bone induction remained unknown until the purification and sequence of bovine BMP3 (osteogenin) and cloning of human BMP2 and BMP4 in the late 1980's (3133). LIF is a member of the interleukin- 6 family of cytokines, including IL-6, oncostatin-M (OSM), ciliary neurotrophic factor (CNTF) and cardiotrophin-1 (ST1). IL-6 cytokine families are structurally and functionally linked. They act on different cells, actually, they are pleiotropic and can mediate proliferation or differentiation or both, according to target cell types $(1,22,28,29,34-37)$.

\section{Why ESCs?}

Because they have not passed the aging period as an adult stem cell, and therefore have a higher potential of potency, clonogenicity and selfrenewal; they are isolated from excess embryos and the method is not invasive or painful; there is no reprogramming, so the transcription of genes has not been impaired, the epigenetic landscape, the potential of differentiation and mutational loads are considerably lower than in the application of iPSCs. And because the ESCs are the gold standard of pluripotency in vitro, comparable to all other types of stem cells (38-40).

\section{Legislation}

Research with hESCs and their use is more controversial than the involving adult stem cells. Usually, hESCs come from embryos that develop from fertilized eggs in vitro. Most of the public opinion is convinced that the embryo has a moral status, which is the main cause of the dilemma about hESCs research $(41,42)$. The hESCs can be differentiated into any type of cell of all three germ layers (21). Human embryonic cells pass through physical changes for implantation in the uterine wall about 57 days after the fertilization. If these cells are isolated and grown in laboratory conditions in the Petri dish, the human embryonic stem cells continue to divide and remain stem cells that can produce all cell types. This type of cells can only be obtained by the destruction of human embryos, which is the reason of the discussion, since the respondents have opposing attitudes regarding whether or not the embryo has a moral status $(41,43)$. Some people believe that embryos or blastocysts are just a bunch of cells that can be used without any limitation. Therefore, they support research with the hESCs provided there is scientific justification, careful supervision and 
consent of a woman or em-bryo research donor (42, $44,45)$. Ethical, religious, national attitudes and insufficient public opinion about research and implementation of hESCs are one of the leading problems in numerous studies. The study of human embryonic stem cells is ethically and politically controversial because it involves the destruction of human embryos. It is not disputed that embryos have the potential to develop into a human being, but only if they are implanted in the uterus of a woman at the appropriate hormonal stage, they can develop into a fetus and become a live baby. However, a large percentage of public opinion is of the conviction that the embryo has the same moral status as an adult or a live-born child, and therefore has interests and rights that must be respected. From this perspective, taking a blastocyst and removing the inner cell mass to obtain human embryonic stem cell lines is similar to murder $(41,42,44,46)$. In many countries including Germany, the Embryo Protection Act is forbidding the creation of supermodern embryos, donation of eggs and embryos; the Stem Cell Act, which came into force in 2002, regulates the study of human stem cells. IVF couples, like most physicians, have voted to legalize the donation and production of embryonic stem cells from embryo surplus (47). In Italy, the legal pro-tection of the embryo has been regulated by the Law on Medical Aid in Reproduction (Law 40/2004) since 2004. Manipulation of embryos is only permitted if used for therapeutic or diagnostic purposes and when there is no alternative. This law does not specify any rule regarding the fate of excess embryos obtained from in vitro fertilization procedures before the law is passed and actually stored in different Reproductive Technology Centers or for potential studies whereby embryonic stem cells are imported from abroad. Autologous storage of embryonic stem cells for personal use is permitted only in case of serious illness, in the case of families at high risk of genetic diseases (48). Very liberal models occur in countries such as Spain, Belgium, Sweden, the United Kingdom, the Czech Republic, Switzerland and Greece where the embryo acquisition/use is allowed for research purposes under the strict supervision of the authorized institutions. In the United Kingdom, the Law on Human Fertilization and Embryology of 2001 encourages the use of embryos for research and therapeutic cloning. In Belgium, Greece and Sweden, embryos are allowed until 14 days after fertilization, and in the Czech Republic up to 7 days after fertilization, but embryo cloning is prohibited. The Court of Justice of the European Union has confirmed that the destruction of embryos should be avoided and it has been ruled that medicines derived from research with human embryonic cells cannot be patented (48).

\section{ESCs use}

\section{Examples of clinical studies for potential}

In addition to the potential use of stem cells in regenerative medicine, transplantation, dentistry, disease modeling, gene therapy, it should be noted that there are certain risks in the occurrence of point mutations that are numerous in tumor cell genes. Therefore, in the use of human induced pluripotent stem cells, it is necessary to check and eliminate the possibility of any mutations on the tumor suppressor genes, as tumorigenesis may occur after implantation in the patient. Human embryonic stem cells can also cause tumorigenesis, as well as transplant rejection $(21,43)$. Stem cells ability to develop into any cell type, maintain tissue and organ health, make them a potential treatment to assist organ and tissue repair after invasive procedures such as surgery. Hepatic administration of autologous hematopoietic stem cells (HSCs) has shown feasibility and safety based on nine published trials reviewed by Stutchfield and colleagues (2010) (49), at the end they suggest further research specifically on the use of ESCs for hepatic engraftment and hepatocyte differentiation (50). ESCs may have potential in facial nerve repair and regeneration based on eight animal trials. The review by Euler De Souza Lucena and colleagues (2014) (51) did not identify any human trials in this area, but it gives us hope and motivation to continue further research. There are promises for stem cell treatment for spinal and brain injury, the review by Tator (2006) (52) identifies pre-clinical research on the use of human ESCs. There are some researches and reviews that noted the potential of ESCs in vitro for tissue-engineering. Trachea and laryngeal tissue were engineered using stem cells (53). Regeneration of tissue-engineered tracheal airway was trialled in one human study with 15 months follow-up and showed complete epitheliali-sation on endoscopy (54). Several reviews by Greeta Shroff and colleagues (55-60) noted the potential use of ESCs treatments. In the case of a 65-year-old male patient with Parkinson's disease (PD) treated with human embryonic stem cell (hESC) significant improvement was noted in the reduction of tremor, bradykinesia, muscle rigidity, pain and stiffness in the neck, shoulders and back, as well as improvement in the range of neck movement. The patient was able to maintain balance while walking, had a stiffness reduction in his left hand and both legs. He could speak louder and improve his writing skills. No adverse effects or teratomas were observed (55). Stem cells therapy has shown positive results in three diabetic (diabetes mellitus-DM) patients. Patients were treated with human embryonic stem cells and that resulted in reduced blood glucose levels. Improved vision, endurance, mental focus and muscle strength were observed. After treatment, undesirable effects and teratoma development have not been reported (56). Research on treatment options for spinal cord injuries (SCI) has been shifted to cellular therapies. The use of human embryonic stem cells (hESCs) in five patients who were paraplegics or quadriplegics showed a significant improvement in sedation, control and sensation of the intestine and bladder, strength and movement of the limbs. Unwanted effects have not been reported (57). Human embryonic stem cells therapy (hESCs) is a potential therapeutic option for treating patients with aplastic anemia (AA). The study showed remarkable improvement in patients with AA after hESCs administration. There were no side effects in patients (58). Empirical therapy with hESCs resulted in the improvement and reduction of symptoms in a patient with pulmonary emphysema (59). It has not been 
established that pharmacological treatment is effective in the treatment of spinocerebellar ataxia. hESCs based therapy appears as a promising therapeutic option for the treatment of spinocerebellar ataxia. Three patients with spinocerebellar ataxia were treated with human embryonic stem cells. After treatment, all patients showed significant changes in their state of health, improved eye coordination, stroke patterns, the ability to stand without support, muscle strength in all limbs, the ability to walk and swing while standing without support, clarity of speech, good energy levels, reduction in muscle twitching, durability and coordination (60). Recent studies have been followed by two open-label phase $1 / 2$ studies two open I/II phases involving 18 patients with age-related macular degeneration (AMD), suggesting that it is possible to safely implant RPE (hESC-RPE) derived from human embryonic stem cells in an attempt to save photoreceptor and visual function. Anatomical and functional results were encouraging with more than half of treated patients experiencing permanent visual acuity enhancements. However, any conclusion remains relative for a short period of time, a lack of a formal control group, a weak initial visual acuity, and a small number of patients. In addition to the case of postoperative infectious endophthalmitis, no adverse effects associated with cell therapy, such as hyperproliferation, tumorigenesis or inflammation associated with rejection, have been observed in this ini- tial 18-patient group. All studies describing the potential therapeutic use of hESCs showed a beneficial effect in the treatment of various diseases, but future clinical trials are needed to gather more evidence to support the findings and enable wider application of these new therapeutic modalities. On the other hand, since they were first isolated more than three decades ago, embryonic stem cells have been proposed as a source of cells in regenerative medicine, but their plasticity and unlimited capacity for self-renewal cause concern over the safety of their use, as there is a risk of tumor formation (teratoma), potential immunological rejection of cells and tissues, and the risk of differentiating into unwanted cell types $(61,62)$.

\section{Conclusion}

The potential use of embryonic stem cells could be a very attractive and important therapy in medicine and certainly belongs to the therapeutic options of the future. However, it has been addressed with various legislative problems and inadequate education of health personnel. Future research should be directed towards education of health personnel and public opinion, change of legislation, which could reflect the increased use of this research and potential therapy with less scepticism.

\section{References}

1. Lanza R, Atala A. Essentials of Stem Cell Biology. $3^{\text {rd }}$ ed. Saint Louis: Elsevier Science; 2014. [CrossRef]

2. Hongxiang $H$, Yongming $T$, Min $H$, Xiaoning $Z$. Stem Cells: General Features and Characteristics. Stem Cells in Clinic and Research, Ali Gholamrezanezhad, IntechOpen 2011. Available from: URL: https://www.intechopen.com/books/stem-cells-inclinic-and-research/stem-cells-general-features-andcharacteristics

3. Gilbert SF. Developmental Biology. $6^{\text {th }}$ ed. Sunderland (MA): Sinauer Associates; 2000.

4. Gilbert SF. Developmental Biology. $8^{\text {th }}$ ed. Sunderland (MA): Sinauer Associates; 2006.

5. Morgani SM, Canham MA, Nichols J, Sharov AA, Migueles RP, Ko MS, et al. Totipotent embryonic stem cells arise in ground-state culture conditions. Cell Rep 2013; 3(6):1945-57.[PubMed][CrossRef]
6. Bonnet D, Dick JE. Human acute myeloid leukemia is organized as a hierarchy that originates from a primitive hematopoietic cell. Nat Med 1997; 3(7):730-7. [PubMed][CrossRef]

7. Al-Hajj M, Wicha MS, Benito-Hernandez A, Morrison $\mathrm{SJ}$, Clarke MF. Prospective identification of tumorigenic breast cancer cells. PNAS 2003; 100(7):3983-8. [PubMed][CrossRef]

8. Singh SK, Clarke ID, Terasaki M, Bonn VE, Hawkins C, Squire J, et al. Identification of a cancer stem cell in human brain tumors. Cancer Res 2003; 63(18):58218. [PubMed]

9. Matsui W, Huff CA, Wang Q, Malehorn MT, Barber J, Tanhehco $Y$, et al.Characterization of clonogenic multiple myeloma cells. Blood 2004; 103(6):2332-6. [PubMed][CrossRef]

10. O'Brien CA, Pollett A, Gallinger S, Dick JE. A human colon cancer cell capable of initiating tumour growth in 
immunodeficient mice. Nature 2007; 445(7123):10610.[PubMed][CrossRef]

11. Ma S, Chan KW, Hu L, Lee TK, Wo JY, Ng IO, et al. Identification and characterization of tumorigenic liver cancer stem/progenitor cells. Gastroenterology 2007; 132(7):2542-56. [PubMed][CrossRef]

12. Li C, Heidt DG, Dalerba P, Burant CF, Zhang L, Adsay $V$, et al. Identification of pancreatic cancer stem cells. Cancer Res 2007; 67(3):1030-7. [PubMed] [CrossRef]

13. Eramo A, Lotti $F$, Sette G, Pilozzi E, Biffoni M, Di Virgilio $A$, et al. Identification and expansion of the tumorigenic lung cancer stem cell population. Cell Death Differ 2008; 15(3):504-14.

[PubMed] [CrossRef]

14. Maitland NJ, Collins AT. Prostate cancer stem cells: a new target for therapy. J Clin Oncol 2008; 26(17): 2862-70. [PubMed] [CrossRef]

15. Zhang S, Balch C, Chan MW, Lai HC, Matei D, Schilder $\mathrm{JM}$, et al. Identification and characterization of ovarian cancer-initiating cells from primary human tumors. Cancer Res 2008; 68(11):4311-20. [PubMed] [CrossRef]

16. Schatton T, Murphy GF, Frank NY, Yamaura K, Waaga-Gasser AM, Gasser $M$, et al. Identification of cells initiating human melanomas. Nature 2008; 451 (7176):345-9. [PubMed] [CrossRef]

17. Takaishi S, Okumura T, Tu S, Wang SS, Shibata W, Vigneshwaran $R$, et al. Identification of gastric cancer stem cells using the cell surface marker CD44. Stem Cells 2009; 27(5):1006-20. [PubMed] [CrossRef]

18. Novosadova EV, Grivennikov IA. Induced pluripotent stem cells: from derivation to application in biochemical and biomedical research. Biochemistry (Mosc) 2014; 79(13):1425-41. [PubMed] [CrossRef]

19. Odorico JS, Kaufman DS, Thomson JA. Multilineage Differentiation from Human Embryonic Stem Cell Lines. Stem Cells 2001;19(3):193-204.

[PubMed] [CrossRef]

20. Stojkovic $M$, Lako $M$, Stojkovic $P$, Stewart $R$, Przyborski S, Armstrong $L$, et al. Derivation of human embryonic stem cells from day-8 blastocysts recovered after three-step in vitro culture. Stem Cells 2004; 22(5):790-7. [PubMed] [CrossRef]

21. Volarevic V, Simovic Markovic B, Gazdic M, Volarevic A, Arsenijevic N, Armstrong L, et al. Ethical and Safety Issues of Stem Cell-Based Therapy. Int J Med Sci 2018; 15(1):36-45. [PubMed] [CrossRef]

22. Thomson JA, Itskovitz-Eldor J, Shapiro SS, Waknitz MA, Swiergiel JJ, Marshall VS, et al. Embryonic stem cell lines derived from human blastocysts. Science 1998; 282(5391):1145-7. [PubMed] [CrossRef]

23. Dolnikov K, Shilkrut M, Zeevi-Levin N, Danon A, Gerecht-Nir S, Itskovitz-Eldor J, et al. Functional properties of human embryonic stem cell-derived cardiomyocytes. Ann N Y Acad Sci 2005; 1047:66-75. [PubMed] [CrossRef]

24. Pera MF, Reubinoff $B$, Trounson A. Human embryonic stem cells. J Cell Sci 2000; 113(Pt 1):5-10. [PubMed]

25. Kim HS, Oh SK, Park YB, Ahn HJ, Sung KC, Kang MJ, et al. Methods for derivation of human embryonic stem cells. Stem Cells 2005; 23(9):1228-33. [PubMed] [CrossRef]

26. Richter KS, Harris DC, Daneshmand ST, Shapiro BS. Quantitative grading of a human blastocyst: optimal inner cell mass size and shape. Fertil Steril 2001; 76 (6):1157-67. [PubMed] [CrossRef]

27. Solter D, Knowles BB. Immunosurgery of mouse blastocyst. Proc Natl Acad Sci USA 1975; 72(12):5099102.[PubMed] [CrossRef]

28. Kehat I, Kenyagin-Karsenti $D$, Snir $M$, Segev $H$, Amit $M$, Gepstein A, et al. Human embryonic stem cells can differentiate into myocytes with structural and func- tional properties of cardiomyocytes. J Clin Invest 2001; 108(3):407-14. [PubMed] [CrossRef]

29. Ying QL, Nichols J, Chambers I, Smith A. BMP Induction of Id Proteins Suppresses Differentiation and Sustains Embryonic Stem Cell Self-Renewal in Collaboration with STAT3. Cell 2003; 115(3):281-92. [CrossRef]

30. Urist MR. Bone formation by autoinduction. Science 1965; 150(3698):893-99. [PubMed] [CrossRef]

31. Wozney JM, Rosen V, Celeste AJ, Mitsock LM, Whitters MJ, Kriz RW, et al. Novel regulators of bone formation: molecular clones and activities. Science 1988; 242 (4885):1528-34. [PubMed] [CrossRef]

32. Luyten FP, Cunningham NS, Ma S, Muthukumaran N, Hammonds RG, Nevins WB, et al. Purification and partial amino acid sequence of osteogenin, a protein initiating bone differentiation. J Biol Chem 1989; 264 (23):13377-80. [PubMed]

33. Wozney JM. The bone morphogenetic protein family and osteogenesis. Mol Reprod Dev1992; 32(2):160-7. [PubMed] [CrossRef]

34. Warburton D. Stem Cells, Tissue Engineering and Regenerative Medicine. University of Southern California, USA: World Scientifc Publishing; 2015.

[CrossRef]

35. Ying QL, Wray J, Nichols J, Batlle-Morera L, Doble B, Woodgett J, et al. The ground state of embryonic stem cell self-renewal. Nature 2017; 453(7194):519-23. [PubMed] [CrossRef]

36. Ying QL, Stavridis M, Griffiths D, Li M, Smith A. Conversion of embryonic stem cells into neuroectodermal precursors in adherent monoculture. Nat Biotechnol 2003; 21(2):183-6. [PubMed] [CrossRef]

37. Chen D, Zhao M, Mundy GR. Bone morphogenetic proteins. Growth Factors 2004; 22(4):233-41. [PubMed] [CrossRef]

38. National Institutes of Health (US). Stem Cells Basics. Bethesda: NIH; 2016.

39. Bilic J, Izpisua Belmonte JC. Concise review: Induced pluripotent stem cells versus embryonic stem cells: close enough or yet too far apart. Stem Cells 2012; 30(1):33-41. [PubMed] [CrossRef]

40. Vats A, Trolley NS, Bishop AE, Polak JM. Embryonic stem cells and tissue engineering: delivering stem cells to the clinic. JRSM 2005; 98(8):346-50. [PubMed] [CrossRef]

41. Hudson KL, Scott J, Faden R. Values in Conflict: Public Attitudes on Embryonic Stem Cell Research. Genetics and Public Policy Center 2005.

42. de Wert G, Mummery C. Human embryonic stem cells: research, ethics and policy. Hum Reprod 2003; 18(4):672-82. [PubMed] [CrossRef]

43. Dresser R. Stem Cell Research as Innovation: Expanding the Ethical and Policy Conversation. J Law Med Ethics 2010; 38(2):332-41. [PubMed] [CrossRef]

44. Lo B, Parham L. Ethical Issues in Stem Cell Research. Endocr Rev 2009; 30(3):204-13. [PubMed] [CrossRef]

45. National Institutes of Health (US). Ad Hoc Group of Consultants to the Advisory Committee to the Director. Report of The Human Embryo Research Panel. Bethesda: NIH; 1994.

46. Walters L. Human Embryonic Stem Cells Research: An Intercultural Perspective. Kennedy Inst Ethics J 2004; 14(1):3-38. [PubMed] [CrossRef]

47. Krones T, Neuwohner E, Bock K, Manolopoulos K, Tinneberg HR, Richter G. Attitudes of patients, healthcare professionals and ethicists towards embryonic stem cell research and donation of gametes and embryos in Germany. Reprod Biomed Online 2006; 13(5):607-17. [PubMed] [CrossRef]

48. Frati $P$, Gulino M, Pacchiarotti A, D'Errico S, Sicuro $L$, Fineschi V. A Survey of Italian Physicians' Opinion 
about Stem Cells Research: What Doctors Prefer and What the Law Requires. Biomed Res Int 2014; 2014: 480304. [PubMed] [CrossRef]

49. Stutchfield BM, Forbes SJ, Wigmore SJ. Prospects for stem cell transplantation in the treatment of hepatic disease. Liver Transpl 2010; 16(7):827-36.

[PubMed] [CrossRef]

50. Atukorale YN, Lambert RS, Cameron AL, Maddern GJ. Stem cell treatments within surgical specialities: what is the evidence? ANZ J Surg 2018; 88(1-2):11-2. [PubMed] [CrossRef]

51. Euler De Souza Lucena E, Guzen FP, Lopes De Paiva Cavalcanti JR, Galvao Barboza CA, Silva do Nascimento Júnior E, Cavalcante Jde S. Experimental considerations concerning the use of stem cells and tissue engineering for facial nerve regeneration: A systematic review. J Oral Maxillofac Surg 2014; 72(5): 100112.[PubMed] [CrossRef]

52. Tator $\mathrm{CH}$. Review of treatment trials in humanspinal cord injury: Issues, difficulties, and recommendations. Neurosurgery 2006; 59(5):957-82. [PubMed] [CrossRef]

53. Wormald JC, Fishman JM, Juniat S, Tolley N, Birchal MA. Regenerative medicine in otorhinolaryngology. ] Laryngol Otol 2015; 129(8):732-9. [PubMed] [CrossRef]

54. Elliott MJ, De Coppi P, Speggiorin S, Roebuck D, Butler C, Samuel E, et al. Stem-cell-based, tissue engineered tracheal replacement in a child: a 2-year follow-up study. Lancet 2012; 380(9846):994-1000. [CrossRef]
55. Shroff G, Hopf-Seidel P. Use of Human Embryonic Stem Cells in the Treatment of Parkinson's Disease. Int J Emerg Ment Health 2015; 17(3):661-3.

56. Shroff G. Use of Human Embryonic Stem Cells in the Treatment of Diabetes Mellitus: A Case Series. J Diabetes Mellitus 2015; 05(04):313-8. [CrossRef]

57. Shroff G, Gupta R. Human embryonic stem cells in the treatment of patients with spinal cord injury. Ann Neurosci 2015; 22(4):208-16. [PubMed] [CrossRef]

58. Shroff G, Gupta R, Zadeng L. Human embryonic stem cell therapy for aplastic anemia; Clin Case Rep 2017; 5(6):919-22. [PubMed] [CrossRef]

59. Shroff G. Human embryonic stem cells (hESCs) in the treatment of emphysematous COPD: a case report. Clin Case Rep 2015; 3(7):632-4. [PubMed] [CrossRef]

60. Shroff G. Human Embryonic Stem Cells in the Treatment of Spinocerebellar Ataxia: A Case Series. J Clin Case Rep 2015; 4:474. [CrossRef]

61. Schwartz SD, Regillo CD, Lam BL, Eliott D, Rosenfeld PJ, Gregori NZ, et al. Human embryonic stem cellderived retinal pigment epithelium in patients with age-related macular degeneration and Stargardt's mae-cular dystrophy: Follow-up of two open-label phase 1/2 studies. Lancet 2015; 385(9967):509-16. [CrossRef]

62. Schwartz SD, Tan G, Hosseini H, Nagiel A. Subretinal Transplantation of Embryonic Stem Cell-Derived Retinal Pigment Epithelium for the Treatment of Macular Degeneration: An Assessment at 4 Years. Invest Ophthalmol Vis Sci 2016; 57: ORSFc1-9. [PubMed] [CrossRef] 
Revijalni rad

UDC: 602.9:611.013.9

doi:10.5633/amm.2019.0320

\title{
EMBRIONALNE MATIČNE ĆELIJE: GDE SMO TRENUTNO?
}

\author{
Sanja Raščanin ${ }^{1}$, Nemanja Rančić ${ }^{2}$, Saša Dragović3 ${ }^{3}$ Mirjana Jovanović1,4 \\ ${ }^{1}$ Univerzitet u Kragujevcu, Fakultet medicinskih nauka, , Kragujevac, Srbija \\ ${ }^{2}$ Centar za kliničku farmakologiju, Vojnomedicinska akademija, Beograd, Srbija \\ ${ }^{3}$ Klinika za opštu hirurgiju, Vojnomedicinska akademija, Beograd, Srbija \\ ${ }^{4}$ Klinika za psihijatriju, Klinički centar Kragujevac, Kragujevac, Srbija \\ Kontakt: Sanja Raščanin \\ Svetozara Markovića 69, 34000 Kragujevac, Srbija \\ E-mail:rsanja.eko@gmail.com
}

Matične ćelije su funkcionalno definisane kao ćelije koje imaju sposobnost da se replikuju i generišu diferencirane ćelije. One mogu generisati višestruko diferencirane tipove ćelija (multipotentne ili pluripotentne) ili mogu proizvesti jedan tip diferenciranih ćelija (unipotentne) u zavisnosti od kapaciteta replikacije i potencijala matičnih ćelija. Danas, matične ćelije mogu imati potencijalnu primenu u regenerativnoj medicini, transplantaciji, lečenju autoimunih, hroničnih i progresivnih bolesti, kao i u modeliranju bolesti. Sada se suočavamo sa dilemom između dva tipa matičnih ćelija koje su pogodnije za istraživanje i terapijsku upotrebu, embrionalne matične ćelije (ESC) i indukovane pluripotentne matične ćelije (iPSC)? ESC predstavljaju zlatni standard pluripotencije u in vitro uslovima, koji upoređuje sve ostale tipove matičnih ćelija, dok je iPSC pogodniji za autologne transplantacije zbog izbegavanja odbacivanja tkiva i zbog odsustva etičkih dilema. Cilj ovog rada bio je predstaviti najvažnije karakteristike ESC koje imaju terapijski značaj.

Acta Medica Medianae 2019;58(3):138-146.

Ključne reči: emrionalne matične ćelije, regulativa, terapija 